\title{
„SCARA LUI IACOB“ ȘI ROSTIREA SCENICĂ
}

\author{
Dan Alb
}

DOI 10.46522/CT.2021.01.03

\begin{abstract}
Jacob's Ladder and Scenic Discourse

Artistic creation (dramatic creation, by choice) restores a path between the everyday life and the celestial one, owing the fact that it is caught between manifestations of the material and those of the ephemeral. Dramatic creation actually wears itself to a shadow while it ascends and descends "Jacob's Ladder", with backward-and-forward movements. Thus, theatre itself acquires a "theurgic" particularity as it magically materializes aspects of the spiritual world. On the one hand, it appeals to the discourse of the imaginary and, on the other hand, it calls down its shapes, which, according to Henry Corbin, could be seen within a utopian world that resides outside the human being.
\end{abstract}

\section{Keywords:}

theatre, imaginary, imaginal, interpretation, theurgy

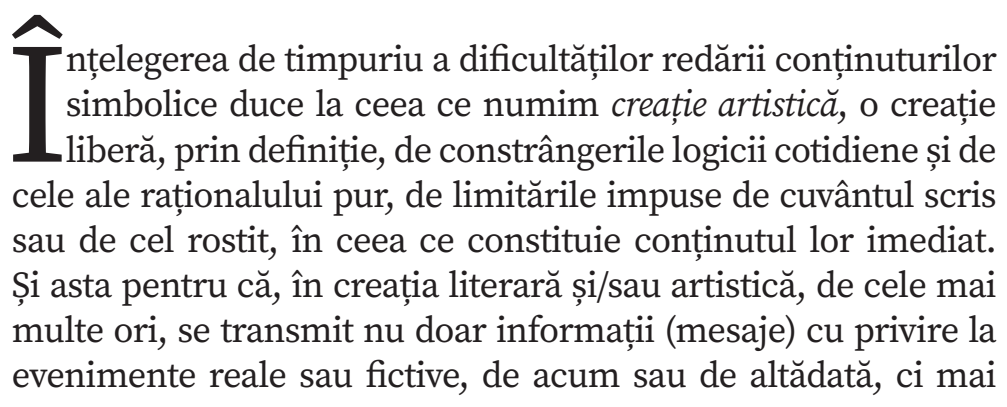


ales un sens conotativ al acestora. Iar, de aici, se ajunge la o înțelegere rafinată a creației artistice, în întregul ei, fiind vizată, de regulă, o bogăție de nuanțe pe care autorul le-a subînțeles sau nu, dar care - volens nolens - sunt închise în structura „obiectului" creat. Mai pot fi luate în discuție limitările impuse de disponibilitatea cititorului de a înțelege mesajul și de a practica jocul intelectiv al cunoașterii. Astfel, putem spune că o operă de artă nu transmite doar acel „ceva“ restrâns la semnificația sa primă, ci, mai ales, o stare unică, metatextuală, care atrage ințelegerea (urmată de cunoașterea și interpretarea) celui care o receptează. $\mathrm{Cu}$ alte cuvinte, opera de artă (figurativă, scenică etc.) există atât prin prisma rezonanțelor afective pe care le provoacă, cât și prin invocarea unui metalimbaj (adică a unui discurs despre sine), analitic, profitabil „răspunsurilor“ teoretice. Cu referire la arta actorului, Jerzy Grotowski spunea: „El (actorul) trebuie să fie capabil să dea viață, prin sunet si mișcare, acelor impulsuri care oscilează la frontiera între vis și realitate. Pe scurt, el trebuie să fie capabil să construiască propriul său limbaj psiho-analitic de sunete și gesturi, tot așa cum un mare poet creează propriul său limbaj de cuvinte“1.

\section{Trăirea scenică - dincolo și dincoace de cuvânt}

Dificultatea limbajului cotidian de a reflecta zonele „rarefiate" ale spiritului - acele zone înnobilate cu un conținut semantic - ține de necesitatea conservării unei funcționalități a comunicării, de impulsul logos-ului de a-și prelungi influențele spre locurile comune, contingente, ale vieții. Pe de alta parte, în artă, chiar și atunci când discutăm despre teatru sau despre producțiile performative subsecvente (destinate unui grup de oameni anume adunați, ca să-1 parafrazăm pe Camil Petrescu²), este părăsit dezideratul „agapei“, al întâlnirii, al colectivității, situație

1. Jerzy Grotowski, Spre un teatru sărac, traducere de George Banu și Mirella Nedelci-Pătureanu, prefața de Peter Brook, postfață de George Banu, București, Editura Unitext, 1998, p. 21.

2. V. Camil Petrescu, Modalitatea estetică a teatrului, București, Fundația pentru Literatură și Artă „Regele Carol II“, 1937: „[...] teatrul e un spectacol organizat, adică este o exhibiție al cărei obiect este o întâmplare reprodusă în fața unei asistențe numeroase în genere convocate." (p. 23). 
în care arta, în diferitele sale variante expresive, nu se mai adresează grupului, ci insului. În acest caz, trăirea - aplicată unui singur individ - nu mai face obiectul transmiterii de informații, fiindu-și „suficientă sieși““, iar limbajul artistic, oricât ne-am strădui să-1 redirecționăm altminteri, nu tinde să devină comun creatorilor și receptorilor operei, întrucât se va adresa ființei și nu grupului social, adică insului pentru care există sens doar în ceea ce arta (de)limitează și nu în ceea ce ea se înscrie ca repetiție. De exemplu, într-un spectacol nu se transmit (verbal sau prin orice alte mijloace) doar semnificații ale unei conjuncturi dramatice, ci, dincolo de asta, și ,înțelegeri“ corijate ale lumii în care trăim, care se pliază pe credințele, opțiunile, trăirile, idealurile, traumele etc. individului și nu pe cele ale spectatorilor, în ansamblul lor. Este vorba aici despre o trăire unică, irepetabilă, o trăire imposibil de reprodus prin mijloacele mimesis-ului. Iar acest mod unic de receptare a creației artistice - care vizează, în mod explicit, o trăire emoțională a ,evenimentului“ - ține, în bună măsură, de accesul la un limbaj de dincolo de cuvinte, de dincolo de sintaxă, un limbaj aparent haotic, și asta pentru că acesta nu este organizat după criterii și norme asumate, după reguli obișnuite. Pe scurt, vorbim despre un logos preluat în interiorul unor structuri continuu reconfigurate și care sunt recunoscute în senzația de armonie a lucrurilor lipsite (în aparență) de sens, o senzație pe care privitorul (sau spectatorul) o trăiește exclusiv în timpul receptării creației.

Aceasta stare, percepută uneori ca exaltare, denotă o congruență internă cu ceva ce nu poate fi definit rațional, dar care reușește, cumva, să comunice cu inconștientul, îmbunătățindu-i condiția. Preluând o metaforă biblică, se poate face o comparație a nivelurilor de agregare a conținuturilor lumii acesteia cu cea care are loc pe diferitele trepte ale scării lui Iacob, cea care, pe de o parte, duce la Cer, pe de altă parte, coboară ,îngerii“ în lumea (in)vizibilă a oamenilor. Dacă privim fiecare treaptă ca pe un nivel de asamblare a informațiilor receptate, rezultă un grad de complexitate din ce în ce mai ridicat, pe măsura îndepărtării de sensul originar a ceea ce ele pur și simplu comunică. Se ajunge, în planuri diferite de reconfigurare a realității, dar și la înțelesuri care ocolesc 
raționalul sau sensul comun, pur funcțional, propriu lucrurilor învederate. Prin renunțarea la caracterul utilitar, se creează premisa dezvăluirii acelor lucruri, mai subtile, care fac obiectul „vorbirii interioare“ și care, în mod curent, sunt „alungate“ în zona inconștientului, acolo de unde ele vor irumpe, din când în când, sub forma așa-ziselor pulsiuni primare, necontrolate (dacă e să acceptăm o direcție psihanalitică). Or tocmai acest caracter necontrolat face ca ele să își păstreze atât autenticitatea, cât și ordinea interioară, chiar în lipsa „disciplinei“ pe care o impun cuvintele și rostirea lor. Această stare originară, numită uneori „de grație“, urmează reguli care nu sunt decelabile în realitatea imediată și nici sub imperativul unei ordini raționale a lucrurilor (cu alte cuvinte, cea care urmărește, mai ales, caracterul funcțional al acestora). De aceea, grila de observație trebuie să fie diferită, dând naștere la forme noi de agregare a atenției, dar și la modalități diferite de organizare a percepției și de translatare a acesteia în înțelesuri particulare. Fiecare treaptă a „scării“ ne face atenți la metaforele invocate, dar și la un nivel de complexitate a vieții care ne îndepărtează de cotidian și ne apropie de o interogare a absolutului. Rămânând în spațiul expresiei metaforice, putem spune că îngerii care urcă și coboară ne pot indica dublul sens al comunicării, între aici și acolo, între vizibil și invizibil, între om și Cer.

\section{Ritual - imaginar - imaginal}

Faptul ca Iacob visează, ne indică și calea de acces la înțelesurile ocultate de cotidian. Ele nu pot fi revelate decât prin abandonare de sine, prin îndepărtarea cenzurii impuse de rațional. Contactul cu acel mundus imaginalis ${ }^{3}$ descris de Henry Corbin (iar, înaintea lui, de Suhrawardi), regăsit în toată mistica, mai ales în cea islamică, nu poate fi realizat prin mijloace ale cunoașterii raționale, de tip dialectic. Formele predilecte de înțelegere și apropriere a înțelesurilor simbolice sunt, în special, de tipul ritualurilor, al ceremonialurilor, al incantației, al mantrelor etc.

3. V. Henry Corbin, Mundus imaginalis or the imaginal and the imaginary, Ipswich, Golgonooza Press, 1976. 
Ierarhia treptelor pare să indice, de asemenea, niveluri de înțelegere diferite, pe care intelectul le poate sonda, pe măsura apropierii de absolut. Odată cu abandonarea sensului, infinite forme de organizare a spiritului își revelează potențialitatea, din care, ulterior, se agregă, abstract, noi forme de manifestare. Prilej de înălțare a spiritului, aceste noi forme, lipsite de constrângeri, fac un dublu circuit: pe de o parte, sunt proiecții ale unei lumi care se gândește pe sine, fixând în absolut viziuni ale ei înseși, pe de altă parte, ele se întorc, pe un traseu descendent, transformând lumea din care au fost create. Astfel, se poate realiza un circuit de la acel mundus imaginalis, creat de mistica persană, la lumea ideilor pure (kantiene), iar, de aici, la inconștientul colectiv de care vorbea Jung ș.a.m.d. Între noi și aceasta lume, există ridicată, așadar, „scara lui Iacob“, ca prim instrument de a transmite înțelesuri spre ambele lumi (cea vizibilă și cea invizibilă), însă prin mijloace care depășesc anvergura limitată a cuvintelor, în sensul lor strict, de purtătoare ale unor semnificații ușor recognoscibile. Dacă luăm, ca exemplu, celebra formulă ,abracadabra“, care ar produce efecte fizice în lumea vizibilă, este evident că nu transmite semnificația logică a cuvântului, ci, așa cum înțelege mistica din toate timpurile, doar modul în care utilizăm "cheia“ (sau formula magică), conectând logosul la o structură a unei lumi imaginale (așa cum o definește Andrei Pleșu în Despre îngeri: „o lume care subzistă și se exprimă ca imagine“44), în fine, cu o formă specifică de manifestare, perceptibilă doar prin simțuri. $\mathrm{Cu}$ alte cuvinte, lumea se creează prin cuvânt, însă nu prin cuvântul ca purtător de semnificație, ci prin rostirea acestuia (prin sunet), producând efecte în lumea sensibilă. Este unul dintre mesajele pe care Antonin Artaud le subliniază în Teatrul și dublul său: „Teatrul care nu se găsește în nimic, dar folosește toate limbajele: gesturi, sunete, cuvinte, foc, strigăte, se regăsește exact în punctul în care are nevoie de un limbaj ca să se manifeste“"

4. Andrei Pleșu, Despre îngeri, București, Editura Humanitas, 2003, p. 58. 5. Antonin Artaud, „Teatrul și cultura”, în: Teatrul și dublul său, urmat de Teatrul lui Séraphin și de Alte texte despre teatru, în românește de Voichița Sasu și Diana Tihu-Suciu, postfață și selecția textelor de Ion Vartic, ediție îngrijită de Marian Papahagi, Cluj-Napoca, Editura Echinox, 1997, p. 13. 


\section{Fundamentul teurgic al creației teatrale}

Sufletul mistic rus, prin sensibilitatea aparte care îl caracterizează, intuiește și dă glas suferinței provocate de ,îndepărtarea de Dumnezeu“, prin clivajul dintre structurile intime ale personalității, cele ținând de natura fundamentală a omului și tipul de personalitate născut sub imperativul funcționalității, mai ales sociale, care face ființa umană să își poată atinge scopurile, în relația cu ceilalți, însă cu prețul renunțării la sine. Tristețea care rezidă din percepția dizarmoniei dintre om și absolut, dintre scopurile sale și împlinirea metafizică de altă natură, nu își găsește rezolvarea decât în artă, înțeleasă nu doar ca expresie manifestă în forme consacrate, dar mai ales în forme de expresie singulare, poate stranii, ale fiecărui individ în parte. „Arta“ oricărui individ, ca într-un fel de estetică a urâtului, devine chiar forma „aberantă“ de manifestare a eului propriu, necenzurat, răspunzând unor pulsiuni primare, uneori hidoase, însă autentice.

Caracterul votiv transpare dincolo de cenzura morală, prin actul autentic original, care se vrea ofrandă a unui suflet nestingherit de bariere sociale sau de alta natură, exprimând o puritate originară, chiar dacă neconformă cu lumea, așa cum este ea structurată de convenții. Omul tânjește după forme de expresie care nu îi sunt la îndemână, pentru că, prin funcționalitate, el pierde înțelesuri, care însă, paradoxal, rămân parte a Ființei lui, devenind limbaj, greu traductibil, încifrat, din perspectivă rațională, un „limbaj“ al inconștientului. Diferența dintre cele două - mai ales neputința de a accede la limbajul inconștientului, pentru a dialoga cu absolutul naște suferința, resimțită cel mai adesea ca neputință de a da curs unei vieți plenare, unitare, de natură să ne împlinească la un nivel diferit de cel al unei simple realizări sociale, materiale sau de alta natură. Tăcerea „surdă“ a inconștientului este resimțită ca durere psihică a neîmplinirii, pierderea scopului de a crea frumusețe, armonizând formele cu esențele care le generează, structurând dinamica personalității în acord cu imperativele unei vieți lăuntrice profunde, integratoare în „marea ecuație universală“. 


\section{Frumosul - între dat și construct}

Frumusețea însă nu este un apanaj al formelor, ci, în egală măsură, ea se naște din ,acorduri interioare“ care așază ființa, sporadic, în congruență cu acel ceva dincolo de noi, pe care cei mai mulți îl numesc Dumnezeu. Fără a-i da o conotație exclusiv religioasă, ci, mai ales, una mistică, spirituală, ideea de Dumnezeu acoperă cel mai bine, în sens larg, aspirația omului spre transcendent, spre acel ceva de care simte că aparține și care îl împiedică să își găsească locul și împlinirea. Calea de acces spre absolutul a cărui intuiție o avem cu toții suscită abordări din cele mai diverse, toate încercând să decodifice un soi de „metalimbaj“ al universului, în conjuncție cu natura umană, „ruptă“ de semnificațiile primare, de înțelesuri și sensuri care fac mai puțin parte din personalitatea funcțională, adaptativă, a omului de astăzi.

Limbajul arhaic, originar, al nucleului ființei umane, care este inconștientul, precedă limbajul articulat, care 1-a înlocuit, eliminându-l, creând bariere greu de surmontat în a accede la conținuturile acestuia, fără recursul la metode inedite, derutante, dar care fac posibilă descoperirea, în parte, a unor sensuri și semnificații proprii inconștientului. Armonia formelor exterioare cu imperative stabilite de inconștient rezidă în percepția frumosului și într-o aliniere a acestora cu reprezentări ale lumii vizibile, sau cu idei clar definite prin limbaj articulat, naște sentimentul de frumos și aduce ființa umană în starea de împăcare cu sine, acea împăcare pe care misticii o asociau extazului.

„Frumusețea va salva lumea“, spunea Dostoievski, rezumând admirabil demersul amplu al omenirii de căutare a sensului, nu doar în perfecțiunea formelor, adică într-un estetism sumar, ci într-o congruență cu sinele, pe care suntem nevoiți să o realizăm, ca să putem să ne „vindecăm“ de starea conflictuală cu noi înșine. „Intenția actului creator artistic este teurgică“, spunea Berdiaev, revelând o cale de acces, o posibilitate de accesare a inconștientului prin artă, dar și o finalitate așteptată, o „vindecare“ a sinelui, prin exprimare. 
Vehiculând conținuturi simbolice și nefiind supus unei logici raționale, inconștientul reclamă intervenția artei pentru a se face înțeles, creând forme și structuri mentale, definite cel mai adesea ca producții ale imaginarului. Ele nu sunt însă fără sens, ci ,vorbesc“ de o lume diferită, o lume posibilă, care așteaptă să fie creată. De aceea, rolul creației teatrale este considerabil, ea posedând, față de alte forme de creație artistică, o versatilitate care îi permite să nuanțeze, să creeze infinite variațiuni, să exprime conținutul simbolic în foarte multe feluri, îmbinând moduri de expresie diferite, ținând de vizual, verbal, auditiv etc., dar și de mijloace subtile de percepție, cum sunt emoțiile. „Calea regală“, însă, prin care se nasc forme ale lumii sensibile, rămâne Cuvântul, înțeles nu doar ca vehicul al semnificației lucrurilor, ci și ca forță creatoare, ca mijloc de traducere a simbolurilor care nasc forme ale lumii vizibile.

Există, în actul rostirii, o puternică încărcătură filosofică, religioasă și, nu în ultimul rând, una curativă, exploatată de toate marile curente de gândire ale omenirii. Depășind sensul originar al vorbirii, de a transmite reprezentări ale lumii vizibile, Cuvântul a devenit (a redevenit) forță, prin puterea de a crea impresii și de a modifica stări de conștiință, vehiculând idei abstracte cu efect în concret, asociind caracterul demiurgic, de imitare a actului creației, cu cel perfect uman, material, de schimbare a lumii fizice. Depășind sensul de purtător al semnificațiilor simbolice, cuvântul și-a recăpătat abilitatea de a schimba lumea în mod direct, prin rostire, așa cum recunosc toate marile religii. În „philosophia perenis“ a oricărei epoci, regăsim nevoia de a schimba arhitectura lumii, de a transforma un loc „neprietenos“ și rece, apropiindu-1 de celest, cu scopul bucuriei care se creează, prin apropierea de divin, prin imitarea formelor arhetipale. Incantația, mantrele și, mai apoi, în creștinism, rugăciunea nu au doar rolul de a transmite încărcătura lor semantică, uneori greu de deslușit; ele devin „porți“, făcând acel ceva, ilogic, dar seducător, care este schimbarea. „Transformați-vă prin înnoirea minții voastre“, zice cel mai gnostic dintre apostoli, Sfântul Pavel, cel care face din Cuvânt un prilej de sărbătoare a spiritului, dincolo de mesaj și limitările impuse de sens, apropiindu-l de Frumusețe, în detrimentul semnificației. 
Etosul lumii relevă, de timpuriu, un soi de „metalimbaj“, cel al săvârșirii, al creației prin abandonarea logicii, o dezvelire a lumilor superioare, fără necesitatea de a o îmbrăca în sensuri comune, inteligibile, adăugând cuvântului mijloace de expresie din categoria sacrului. Gesturile rituale, dincolo de încărcătura simbolică a mesajului pot fi privite ca mijloc de exprimare a unui interior profund, care păstrează nostalgia originilor. Amintirea unui trecut incert, de dinainte de logică, naște fiorul mistic și conflictul interior al neputinței de a se elibera.

Ceea ce reușește creația teatrală este să descătușeze ființa de sensul comun, impus prin normative ale societății și calchiat imperfect pe structura arhaică a psihicului uman, reconciliindu-l cu acele structuri și forme ale unei lumi suprasensibile, din care ne nutrim și către care tindem în cele mai ascunse dintre pulsiuni, dar și în cele mai nobile idealuri și în cele mai frumoase forme de manifestare pe care spiritul uman le concepe. Rolul „tămăduitor“ al artei scenice începe cu acceptarea non-sensului, a operațiilor ilogice și continuă cu generarea frumosului prin revelarea acelor căi ale inconștientului care aduc la suprafață conținuturi simbolice, armonizându-le cu personalitatea celui care tânjește la absolut. În acest sens, arta devine teurgie, mijloc de rezolvare a conflictului cu sine însuși, prin evocarea lumii de dincolo de noi, fapt aducător de liniște interioară.

\section{Bibliografie:}

GRoTowski, Jerzy, Spre un teatru sărac, traducere de George Banu și

Mirella Nedelci-Pătureanu, prefața de Peter Brook, postfață de George Banu, București, Editura Unitext, 1998.

Petrescu, Camil, Modalitatea estetică a teatrului, București, Fundația pentru Literatură și Artă „Regele Carol II“, 1937.

CORBIN, Henry, Mundus imaginalis or the imaginal and the imaginary, Ipswich, Golgonooza Press, 1976.

PleșU, Andrei, Despre îngeri, București, Editura Humanitas, 2003. ARTAUD, Antonin, „Teatrul și cultura“, in: Teatrul și dublul său, urmat de

Teatrul lui Séraphin și de Alte texte despre teatru, în românește de Voichița Sasu și Diana Tihu-Suciu, postfață și selecția textelor de Ion Vartic, ediție îngrijită de Marian Papahagi, Cluj-Napoca, Editura 